\title{
Effect of Egg White Utilization on the Physico-Chemical and Sensory Attributes of Protein-rich Yoghurt
}

\author{
Lilian A. Gogo ${ }^{a}$, Kennedy O. Gogo ${ }^{\text {}}$, Peter L. Shalo ${ }^{a}$, And Symon M. Mahungu ${ }^{a}{ }^{*}$ \\ ${ }^{\mathrm{a}}$ Department of Dairy and Food Science and Technology, Egerton University, P.O. Box 536-20115, Egerton, \\ Kenya \\ ${ }^{a}$ Department of Clinical Medicine, Egerton University, P.O. Box 536-20115, Egerton, Kenya \\ *smahungu@yahoo.com
}

Received: 4 June 2011; Published online: 18 April 2012

\begin{abstract}
High protein yoghurt was made from whole milk, fortified with egg white $(30 \% \mathrm{v} / \mathrm{v})$ and skim milk powder at $12 \%(\mathrm{w} / \mathrm{v})$. Different yoghurt mixes, with albumin content of $15 \%, 30 \%$ and $45 \%(\mathrm{v} / \mathrm{v})$, were prepared. The control was made from whole milk, fortified with skim milk powder at $12 \%(\mathrm{w} / \mathrm{v})$. The blended premixes were pasteurized at $74^{\circ} \mathrm{C}$ for 4 seconds, cooled and then inoculated with $3 \%$ $(\mathrm{w} / \mathrm{v})$ Direct Vat Set yoghurt starter culture at $45^{\circ} \mathrm{C}$. After fermentation for 3 hours in a water bath maintained at $46 \pm 1^{\circ} \mathrm{C}$, product was cooled to $5^{\circ} \mathrm{C}$ and then stored for 24 hours. The effect of the fortification on physico-chemical and sensory properties was investigated. Protein content increased to $8.50 \%$ at $45 \%$ egg white utilization. Susceptibility to wheying was reduced in egg-white fortified samples, without significant difference in sensory attributes of the test samples compared to the control. Sensory analysis showed that yoghurt fortified with $45 \%$ egg white was organoleptically acceptable. The yoghurt was rated as having better sensory appeal as compared to the control.
\end{abstract}

Keywords: Yoghurt; Utilization; Egg White; Protein content

\section{Introduction}

Yoghurt has been described by Rasic and Kurmann (1978) as a coagulated milk product obtained by lactic acid fermentation through the action of Lactobacillus delbrueckii subsp. bulgaricus and Streptococcus salivaris subsp. thermophilus on milk. Consumers' interest in variety and different attributes of fermented milks has led to the fortification of yoghurt with various ingredients. Ayar, Sert, Kalyoncu, and Yazici (2006) reported adding fruits to improve the emulsion viscosity of yoghurt, while Hashim, Khalil, and Afifi (2009) reported addition of date fibre to improve texture and health functionality of yoghurt. Other food sources used for formulation include soy milk (Granata \& Morr, 1996), grape juice (Kumar \& Mishra, 2004), and a combination of mango pulp-soy milk and buffalo milk (Öztürk \& Öner, 1999). Fortification methods for yoghurt milk increase not only the solids content, but also the protein content (casein in particular) as a percentage of milk solids (Kumar \& Mishra, 2004). Fortification with skim milk powder (SMP) is commonly used to increase the solid content in conventional yogurt manufacture. However, when enrichment of the protein content is the main target, the amount of SMP that can be added to provide extra protein content is limited. Too high levels of SMP can lead to a powdery taste and high lactose content, which ultimately results in a highly acidic product (Mistry \& Hassan, 1992; Bienvenue, JiménezFlores, \& Singh, 2003). Moreover, the thermal degradation of proteins during SMP production can be very important in these cases, diminishing 
the nutritional value of the yogurt. An alternative approach to fortification of the milk for yoghurt manufacture is by ultrafiltration. (Solanki \& Rizvi, 2001; Bienvenue et al., 2003; Karlsson, Ipsen, Schrader, \& Ardo, 2005). Other ingredients such as casein based products (Everett \& McLeod, 2005), whey protein-based ingredients (Amatayakul, Sherkat, \& Shah, 2006a; Supavititpatana, Wirjantoro, \& Raviyan, 2009) and soy protein (Granata \& Morr, 1996; Karleskind, Laye, Halpin, \& Morr, 1991; Kumar \& Mishra, 2004) have been used to increase the protein content of yoghurt. On the other hand, egg white is a valuable protein ingredient (Lewko \& Gornowicz, 2009) as determined by its essential amino acid composition, digestibility and bioavailability of the amino acids. It is characterized by a unique biological value and a digestibility that is the highest among known protein foods (Gutierrez, Takahashi, \& Juneja, 1997). Egg white has a protein efficiency ratio of 3.8 , protein digestibility of 100, amino acid score of 188 and biological value of 100 (Layman \& Rodriguez, 2009). Even though egg white has been used in many food applications because of its excellent functional properties (Guang \& Tong, 2009), information concerning the utilization of egg white for yoghurt milk protein fortification is scarce. Increased protein intakes and supplementation have generally been focused on athletic populations, enhancing weight reduction and special population groups like the sick, children and geriatrics. (Hoffman \& Flavo, 2004). The current work investigated formulation and physical and sensory properties of high protein yoghurt manufactured using egg white. There are applications of the findings for the benefit of the poor sick people, especially those living with HIV/AIDS complications in the developing countries, who require high density protein foods but cannot afford the products in the market.

\section{Materials and Methods}

\subsection{Yoghurt formulation and pasteurization}

The method of mass balance described by Earle (1969) was used to obtain the final product pro- tein content. The total weight of protein sources of raw ingredients and the amounts of protein to be contributed by each protein source in the final product protein content was obtained. Then, the desired percent protein in the final product was calculated. A temperature and time combination of $74^{\circ} \mathrm{C}$ for 4 seconds was used for the pasteurization of the egg white enriched products.

\subsection{Preparation of yoghurt premix}

Egg white was separated from yolk of broken whole egg, and added in various ratios to the whole milk and skim milk powder $(12 \% \mathrm{w} / \mathrm{v})$ blend to produce premixes with egg white content ranging from $0 \%, 15 \%, 30 \%$ and $45 \%(\mathrm{v} / \mathrm{v})$. The experiment consisted of three treatments. Treatments involved enrichment with albumen at $15 \%, 30 \%$, and $45 \%(\mathrm{v} / \mathrm{v})$. A control mix fortified only with Skimmed Milk Powder was prepared for comparison. The final mixes were prepared at $45^{\circ} \mathrm{C}$ using a high speed blender for 1 minute, while sugar was added at $6 \%(\mathrm{w} / \mathrm{v})$. Samples were then used for the manufacture of yoghurt.

\subsection{Yoghurt manufacture}

The batch method outlined by Rasic and Kurmann (1978) was modified and used for yoghurt manufacture. The premix blends were transferred into one litre stainless steel containers (SS $18 / 8$ type) and pasteurized by gradually heating the mix to $74^{\circ} \mathrm{C}$ (using a water bath maintained at $75 \pm 1^{\circ} \mathrm{C}$ ) and maintaining it at this temperature for 4 seconds. Each sample was quickly cooled to $45^{\circ} \mathrm{C}$ and inoculated with $3 \%(\mathrm{w} / \mathrm{v}) \mathrm{Di}$ rect Vat Set (DVS) yoghurt starter culture (Chr. Hansen Co. Ltd). The inoculated yoghurt premix was stirred for 1 minute, and then covered with a lid, prior to incubation for 3 hours in a water bath maintained at $46 \pm 1^{\circ} \mathrm{C}$. Following incubation, the yoghurt was stored for at least 24 hours at $5^{\circ} \mathrm{C}$ under forced-air cooling to stop further acid development. Triplicate analyses for physico-chemical and sensory tests were carried out on the yoghurt after 24 hours of storage. Viscosity and syneresis tests were performed after 5 days of storage. 


\subsection{Phosphatase test}

A simple phosphatase test described by Marth (1978) was performed. About $10 \mathrm{mls}$ of the yoghurt samples were mixed with $1 \mathrm{ml}$ of phosphatase solution (Fisher Scientific, UK) containing added phosphatase buffer. About $1 \mathrm{ml}$ of the yoghurt and phosphatase mix was placed in a water bath maintained at $37^{\circ} \mathrm{C}$ for 30 minutes. Color development was noted by comparing the color of boiled milk on the left with the sample on the right in a Lovibond comparator (Code AF332, Tinto ltd, UK). Colors were judged to the nearest disc number using daylight. The sample was placed in a water bath for a further 90 minutes and readings taken for an indication of phosphatase activity.

\subsection{Compositional analysis}

Compositional analysis for yoghurt was performed following the Association of Official Analytical Chemists (AOAC, 1990) methods, including No. 991.20 for protein content, No. 905.02 for fat analysis, No. 945.46 for ash measurement, No. 990.20 for moisture content determination, No. 926.08 for total solids content and No. 947.05 for titratable acidity. Assessment of keeping quality was carried out by monitoring changes in lactic acid content during storage for the first five days.

\subsection{Syneresis and viscosity measurements}

Syneresis measurements were performed 5 days after storage. Approximately $9 \mathrm{ml}$ aliquots of the test samples were analysed for susceptibility to syneresis. The method described by Lucey (2004) was modified for this test. Samples were centrifuged at $6^{\circ} \mathrm{C}$ for 10 minutes at different speeds ranging from 2000-6000 rpm. The clear supernatant obtained was aspirated using a needle into a graduated syringe. The total volume of the supernatant measured at each speed was obtained to get the speed where the highest amount of whey was exuded from the samples. At this speed, histograms were plotted of whey in mls against the \% egg white added as an arbitrary indicator of the susceptibility of the particular treatment to syneresis. The method for viscosity measurement described by Parnell-Clunies, Kakuda, Mullen, and Arnott (1986) was used. It involved recording the time taken for products to flow though an eight millimeter orifice. 350 $\mathrm{g}$ of the sample was placed in the funnel of post humus, with the orifice closed using one finger. A stopwatch was started as soon as the finger was withdrawn and stopped when the first break occurred in the issuing stream. The elapsed time was recorded to give an empirical value of viscosity. This measurement was carried out at room temperature $\left(22^{\circ} \mathrm{C}\right)$.

\subsection{Sensory Evaluation}

A quantitative descriptive analysis (QDA) method described by Gisela (1985) and Larmond (1987) was used. The sensory evaluation was carried out by a trained panel consisting of 20 judges aged between 20 and 27 years. They were instructed in the process of evaluating the different parameters of the sensory quality of yoghurt. Choice of panelists was based on availability, non-allergenicity to the taste product, and a demonstration of their ability to follow instructions and carry out appropriate tests in the manner required. A $13.5 \mathrm{~cm}$ line, with word anchors located $1.5 \mathrm{~cm}$ from each end, was used, and the scale direction ran from left to right with increasing intensity. Word anchors used included weak to strong for acidity while the words smooth to coarse were used to define both texture and consistency. The task of the panelist was to make a vertical line across the horizontal line at the point that best reflected the relative intensity for the attribute. The distance along the line to the mark was measured using a millimeter ruler to yield numerical values for computation. The following quality properties were evaluated: appearance, sensory acidity, consistency, and texture. Difference testing was carried out to evaluate the sample differences from the control. Consumer acceptance testing was carried out using 60 untrained teaching and non-teaching staff and students of Egerton University, Kenya. A survey was conducted on age, sex and how often the consumers ate or drunk yoghurt. Four samples 
$(0 \%, 15 \%, 30 \%$ and $45 \%$ enrichment levels) were rated using a 9-point hedonic scale. The scale was used from the left to the right end of the line scale. The adjectives extremely, very much, moderately, slightly and neither like nor dislike were used to express levels of like or dislike in the hedonic scale. Each sample was rated on its own individual scale. The consumers' task was to taste the samples one at a time and select a word descriptor that best expressed their opinion of the sample.

\subsection{Statistical Analysis}

Analysis of variance (ANOVA) was conducted to evaluate differences between treatment means using ("Minitab Statistical Guide Version 14," 2004) and means compared by least significant difference. A randomized block design was used for this study to take account of the variations between panelists. Critical value of differences was determined by use of tables as reported by Amerine, Pangborn, and Roessler (1965) for difference tests. Rank sums were obtained for ranking tests, to determine critical value of differences, using tables presented by Gisela (1985). The Chi-Square test was used in consumer counts to establish significance of differences in age, preference of samples and how often the panelists consumed yoghurt. All analyses were carried out at the $5 \%$ level of significance.

\section{Results and Discussion}

\subsection{Chemical Composition}

The mean values of chemical composition and viscosity for yogurt mixes are shown in Table 1. Significant differences $(\mathrm{P}<0.05)$ among yoghurts mixes as to total solids, protein, and moisture contents were observed. The chemical composition of egg white used in the manufacture of yoghurt contributed to the increase of the total solids content in favour of protein and to the increase of the ash content of the yoghurt mixes. The maximum protein content was $8.5 \%$; associated with a $24.68 \%$ total solids. This was equivalent to approximately $56.8 \%$ protein on the basis of dry matter compared with $36.1 \%$ for the control. Eggs are a rich source of nutrients and egg protein is used as a standard for rating other sources of proteins (Stadelmann, 1992). SMP used to increase the total solids also increased the protein content. SMP is commonly added at a rate of $6 \%$ to increase the total solids of yoghurt, improve the viscosity and texture of the product (Rasic \& Kurmann, 1978). In this study, SMP was added at $12 \%$, which blended well with the dilution effect that occurred after introducing egg white with $74 \%$ water. Rasic and Kurmann (1978) and Tamine and Deeth (1980) reported using milk proteins to increase the protein content of yoghurt. However, the authors indicated excessive acid production and taste deviation in yoghurt when SMP is added at high levels. Albumin enrichment decreased the $\%$ moisture content and increased the \% total solids. These responses were highly significant $(\mathrm{P}<0.01)$. The increase in total solids $(23.15$ to $24.68 \%)$ and decrease in moisture content $(76.85$ to $75.32 \%$ ) indicated that the nutrient density increased in all the enriched products compared to the control. The reduction in moisture content resulted from the use of $12 \%$ SMP with low moisture content. The egg albumin used also has low moisture content of $74 \%$ compared to whole milk that has $87.5 \%$. Ash values of egg white enriched yoghurt $(15 \%, 30 \%$ and $45 \%)$ significantly $(\mathrm{P}<0.05)$ increased from 0.53 to 0.96 . All the means for activity were lower than the normal expected activity of 0.4 , hence the reduction in overall sensory lactic acid content of the egg albumin enriched products.

\section{$3.2 \quad$ Viscosity}

Differences in the apparent viscosity were observed among different yogurt samples. These differences might be attributed to the differences in total protein content associated with differences in added albumin. As expected, yoghurts made with added albumin had in all cases a higher viscosity than SMP fortified yoghurt (control). Addition of albumin at $15 \%(\mathrm{v} / \mathrm{v})$ to the yoghurt premix gave the highest viscosity whilst samples with higher added albumin had lower viscosities than the yoghurt prepared without albumin. Many authors reported significantly

IJFS | April 2012 |Volume 1 pages 52-60 
Table 1: Mean ${ }^{1}$ chemical composition and viscosity ${ }^{2}$ of the protein enriched yoghurt

\begin{tabular}{lccccc}
\hline$\%$ Enrichment & \%Protein & \%Ash & \% Total solids & \% Moisture & Flow time (s) \\
\hline 0 & $5.85^{c}$ & $0.53^{b}$ & $23.15^{b}$ & $76.85^{a}$ & 48.15 \\
15 & $6.33^{c}$ & $0.86^{a}$ & $23.48^{b}$ & $76.52^{a}$ & 53.27 \\
30 & $7.80^{b}$ & $0.81^{a}$ & $24.33^{a}$ & $75.35^{b}$ & 40.13 \\
45 & $8.50^{a}$ & $0.957^{a}$ & $24.68^{a}$ & $75.32^{b}$ & 41.13 \\
\hline LSD at 5\% & 0.52 & 0.26 & 0.66 & 0.56 & 2.31 \\
SE & 0.17 & 0.08 & 0.20 & 0.17 & 0.83 \\
\hline
\end{tabular}

${ }^{1}$ Means obtained from 4 trials for protein and 3 for ash, moisture and total solids

2 Product viscosity determined as flow time in seconds

${ }^{3}$ Means followed by the same superscript letter on the same column are not significantly different $(\mathrm{P}>0.05)$

${ }^{4}$ LSD - Least Significant Difference

${ }^{5} \mathrm{SE}$ - Standard Error of the mean

higher gel firmness and viscosity in yoghurts produced from ultra filtered milk than in yoghurts produced by addition of milk powder (Savello, 1995; Becker \& Puhan, 1989; Uysal, Kilic, Kavas, Akbulut, \& Kesenkas, 2003). Becker and Puhan (1989) demonstrated that ultra filtration results in firmer non-fat yoghurts with higher viscosity than those prepared to the same solids nonfat content by addition of SMP. Savello (1995) found that the greater viscosity of yoghurts produced from ultra filtered milk occurred despite the higher average total solids in the SMP yogurts $(12.98 \%$ vs. $11.43 \%)$.

\subsection{Changes in lactic acid content and syneresis}

The percentage lactic acid content was higher than the control yoghurt. The keeping quality was improved for the first five days of storage. The improvement on keeping quality was highly significant $(\mathrm{P}<0.01)$ for treatments and days (Figure 1). The lowest acidity was observed in the enriched products and differences in treatment means were highly significant. However, the mean change in percentage lactic acid between days was not significant. This was probably due to product refrigeration which stopped further acid development. Product vulnerability to syneresis at $3000 \mathrm{rpm}$ for different levels of enrichment is shown in Figure 2. The various levels of enrichment with egg albumin had no sig-

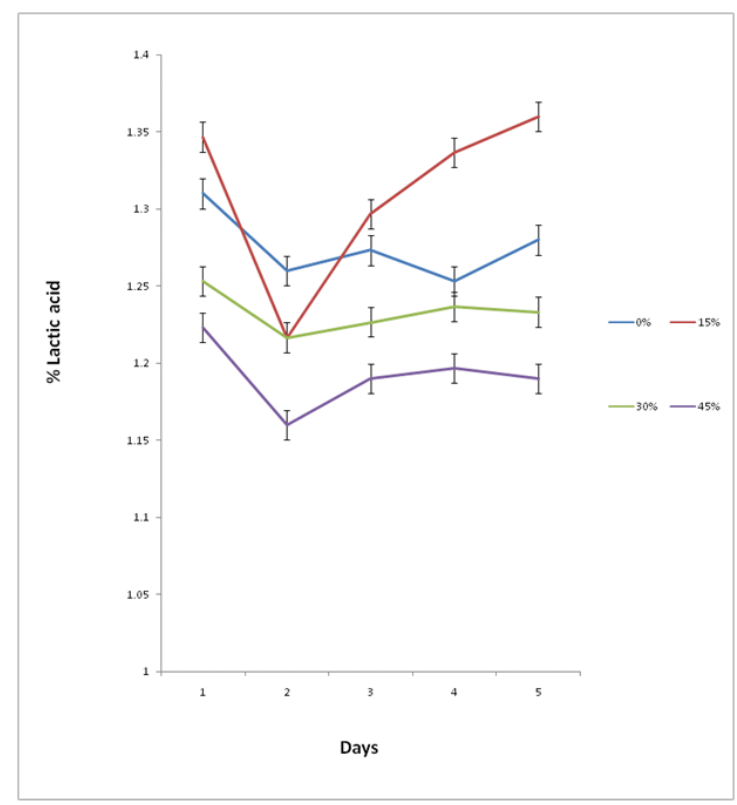

Figure 1: \% Mean lactic acid for the first five days of cold storage. $45 \%$ Indicates percent added albumin (v/v) in the yoghurt premix. Means are obtained from three trials $\mathrm{R}^{2} 0.9752$

nificant influence on the vulnerability of yoghurt to whey separation $(\mathrm{P}>0.05)$. Only the speed of centrifugation affected whey separation. The highest volume of whey was separated at a speed of $3000 \mathrm{rpm}(5000 \mathrm{~g})$ that gave more distinct volumes of whey at different levels of albumin addition (Figure 2). Higher protein content of yoghurt has been shown to reduce the susceptibility of yoghurt to wheying off (Savello, 1995; Am- 
Utilization of Egg White in the Production of Protein-rich Yoghurt $\mid 57$

Table 2: Mean ${ }^{1}$ trained panel scores for sensory properties of egg protein enriched yoghurt

\begin{tabular}{lllc}
\hline Sample & Appearance $^{2}$ & Consistency $^{2}$ & Acidity $^{3}$ \\
\hline No enrichment & $7.82^{a}$ & $7.22^{a}$ & $6.06^{1}$ \\
Whole egg enriched & $2.89^{c}$ & $2.43^{c}$ & $3.82^{b}$ \\
Albumin enriched & $5.60^{b}$ & $5.18^{b}$ & $23.80^{b}$ \\
\hline LSD & 1.23 & 0.95 & 1.27 \\
SE & 0.44 & 0.33 & 0.44 \\
\hline
\end{tabular}

${ }^{1}$ Means values from 20 trials on sensory evaluation

2 Overall appearance and consistency on a line scale running from left (smooth - best quality) to right (coarse - lowest quality)

3 Overall sensory acidity judged on a line scale anchored on two words (weak on the left side of scale - best quality, least score; strong on the right side of scale-lowest with highest score).

${ }^{4}$ LSD - Least Significant Difference at 5\%

${ }^{5} \mathrm{SE}$ - Standard Error of the mean

atayakul, Sherkat, \& Shah, 2006b). Generally, higher total solids cause an increase in density, and reduce pore size in the protein matrix of the yoghurt gel, consequently reducing syneresis and improving the water holding capacity of the gel (Remeuf, Mohammed, Sodini, \& Tissier, 2003; Amatayakul et al., 2006a). High acidity caused by skim milk together with reduced buffer capacity (Rasic \& Kurmann, 1978) has however been found to induce syneresis. Buffer activity could have been greatest at $45 \%$ addition compared to the control.

\subsection{Sensory evaluation}

The sensory parameters determined by trained panel for the yoghurt are given in Table 2. Utilization of whole egg in the manufacture of yoghurt produced a significantly $(\mathrm{P}>0.05)$ better tasting yoghurt. There were highly significant $(\mathrm{P}>0.05)$ differences in the sensory properties of appearance, consistency and acidity among the treatment means. However on mean separation, there were no differences in the acidity scores. There was no egg after taste in the albumin enriched products (Stadelmann, 1992). Both chemical and sensory acidity were similar for egg white enriched and control samples. This could have been due to the addition of high amounts of skim milk powder $(12 \%)$ which has been reported to cause higher than normal acidity in yoghurt (Rasic \& Kurmann, 1978). The lower
Whey exuded at $5000 \mathrm{~g}$

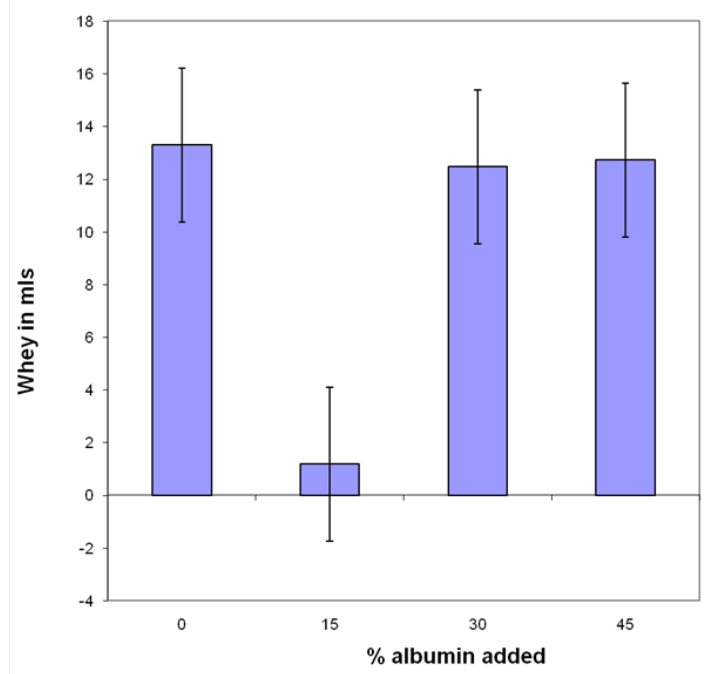

Figure 2: Product vulnerability to syneresis at $3000 \mathrm{rpm} / 5000 \mathrm{~g}$ for different levels of enrichment. Mean values of whey from three trials

acidities observed in the egg enriched products were probably due to initial neutralization effects from the basic egg albumin introduced. Samples with $15 \%$ enrichment were rated the best in appearance (smooth-highest score) and 45\% enrichment as poorest (Table 2). The control product had better texture than the enriched products. Increased egg white utilization did not, however, significantly affect the texture of the 
Table 3: Mean $^{1}$ consumer scores for sensory evaluation of protein enriched yoghurt

\begin{tabular}{llllr}
\hline Treatment & Appearance $^{2}$ & Texture $^{3}$ & Acidity $^{4}$ & Means $^{5}$ \\
\hline $0 \%$ & $2.11^{c}$ & $1.33^{c}$ & $5.88^{a}$ & 7.23 \\
$15 \%$ & $1.46^{c}$ & $1.16^{c}$ & $2.32^{b}$ & 7.26 \\
$30 \%$ & $5.01^{b}$ & $3.32^{b}$ & $1.34^{c}$ & 7.29 \\
$45 \%$ & $6.48^{a}$ & $4.56^{a}$ & $1.37^{c}$ & 7.35 \\
\hline LSD & 1.04 & 1.03 & 0.86 & 1.86 \\
SE & 2.72 & 2.66 & & \\
\hline
\end{tabular}

${ }^{1}$ Means obtained from 60 observations. Means followed by the same superscript letter on the same column are not significantly different $(\mathrm{P}>0.05)$

2 Appearance rating on a line scale running from left (smooth-the best with least score) to right (coarse - the worst with highest score)

3 Texture rating on a line scale running from left (smooth - lowest score) to right (coarse - highest score)

4 Sensory acidity measured on a line scale

${ }^{5}$ Overall mean ratings from 60 consumer panelists rated on a 9-point hedonic scale ranging from extreme like (highest score $=9$ ) to extreme dislike (lowest score $=1$ )

${ }^{4}$ LSD - Least Significant Difference at $5 \%$

${ }^{5} \mathrm{SE}$ - Standard Error of the mean

experimental yoghurt. There was no significant difference $(\mathrm{P}>0.05)$ in the acidity of any of the enriched products and control. A slight decrease was, however, observed in acidity with increase in egg white addition. The control had the highest acidity, while least acidity was observed at $45 \%$ egg white utilization. Ranking test results rated $15 \%$ enrichment as the sample most preferred (rank sum - 38) and the control as least preferred (rank sum 65). These preferences were highly significant (Gisela, 1985). There was a significant preference for $30 \%$ enrichment (rank sum - 41) while that at $45 \%$ enrichment was insignificant (rank sum - 53). Lower ratings for texture may probably have resulted from inclusion of air bubbles from whipped egg white during blending with milk. The high protein content from addition of skim milk powder improved the consistency of experimental yoghurts. Panelists want a smooth textured and smooth appearing product without any lumps (Bianchi-Salvadori \& Zambrini, 1988). Panelists who preferred the control yoghurt were found to have a liking for high acidity, while those without such a liking preferred the enriched products. The enriched product was, however, the most preferred.

\subsection{Consumer acceptance}

A total of 60 panelists ( 34 male \& 26 female) aged between 16 and 60 were used in consumer acceptance tests. There was no significant differ- ence $(\mathrm{P}>0.05)$ in the yoghurt consumption patterns of the panelists as 21 of them drunk yoghurt several times a week, 27 several times a month and 12 drunk yoghurt several times a year. The order of preference was 18 at $45 \%$ enrichment, 17 at $30 \%, 16$ at $15 \%$ and 9 for the control respectively. This difference in preference of the product was significant. There was an insignificant increase in preference with increase in the amount of added egg albumin (Table 3). However, yoghurt enriched with albumin at the $45 \%$ level obtained the highest mean score and hence was most preferred. A significant difference (P $>0.05$ ) between individual consumer ratings for the products was observed, indicating independence in all the judgments made.

\subsection{Conclusions}

High protein yoghurt can be made from whole milk fortified with SMP and egg albumin similar to those enriched with proteins from milk and other non-milk sources. Additional stabilizers are not needed to prevent whey separation, which is the common defect in protein fortified yoghurts. In this study addition of egg albumin improved the chemical and sensory properties of yoghurt. 
Utilization of Egg White in the Production of Protein-rich Yoghurt 59

\section{References}

Amatayakul, T., Sherkat, F., \& Shah, N. P. (2006a). Physical characteristics of set yoghurt made with altered casein to whey protein ratios and eps-producing starter cultures at 9 and $14 \%$ total solids. Food $\mathrm{Hy}$ drocolloids, 20(2-3), 314-324. doi:10.1016/ j.foodhyd.2005.02.015

Amatayakul, T., Sherkat, F., \& Shah, N. P. (2006b). Syneresis in set yogurt as affected by eps starter cultures and levels of solids. International Journal of Dairy Technology, 59(3), 216-221. doi:10.1111/j.1471-0307. 2006.00264.x

Amerine, A., Pangborn, M., \& Roessler, B. (1965). Principles of sensory evaluation of food. New York and London: Academic Press.

AOAC. (1990). Official methods of analysis of the association of official analytical chemists (15th ed.). Washington, DC: Association of Official Analytical Chemists.

Ayar, A., Sert, D., Kalyoncu, I., \& Yazici, F. (2006). Physical, chemical, nutritional and organoleptic characteristics of fruit added yogurts. Journal of Food Technology, 4, 4449. Retrieved from http://docsdrive.com/ pdfs / medwelljournals / jftech/2006/44-49. pdf

Becker, T., \& Puhan, Z. (1989). Effect of different processes to increase the milk solids nonfat content on the rheological properties of yogurt. Milchwissenschaft-milk Science International, 44(10), 626-629.

Bianchi-Salvadori, B., \& Zambrini, A. (1988). Quality control of fermented milks, In Bulletin of the idf. fermented milks- science and technology (227, pp. 115-126).

Bienvenue, A., Jiménez-Flores, R., \& Singh, H. (2003). Rheological properties of concentrated skim milk: influence of heat treatment and genetic variants on the changes in viscosity during storage. Journal of Agricultural and Food Chemistry, 51 (22), 64886494. Cited By (since 1996): 9. doi:10.1021/ jf034050+

Earle, R. (1969). Unit operations in food processing. New York: Pergamon press.
Everett, D. W., \& McLeod, R. E. (2005). Interactions of polysaccharide stabilisers with casein aggregates in stirred skimmilk yoghurt. International Dairy Journal, 15(11), 1175-1183. doi:10.1016/j.idairyj. 2004.12.004

Gisela, J. (1985). Sensory evaluation of food. theory and practice. Deerfield Beach, USA: (Ellis Horwood series in food science and technology) VHC Publishers.

Granata, L. A., \& Morr, C. V. (1996). Improved acid, flavor and volatile compound production in a high protein and fiber soymilk yogurt-like product. Journal of Food Science, 61 (2), 331-336. doi:10.1111/j.13652621.1996.tb14188.x

Guang, W., \& Tong, W. (2009). Restoration of foaming properties of yolk-contaminated liquid egg white by treating with basic soy protein isolate. Journal of Food Science, $74(8), 581-587$.

Gutierrez, M., Takahashi, H., \& Juneja, L. (1997). Nutritive value of hen eggs. In T. Yamamoto \& H. a. K. M. Juneja L.R. abd Hatta (Eds.), Hen eggs (pp. 25-35). CRC Press Inc., Boca Raton.

Hashim, I. B., Khalil, A. H., \& Afifi, H. S. (2009). Quality characteristics and consumer acceptance of yogurt fortified with date fiber. Journal of dairy science, 92(11), 54035407. Cited By (since 1996): 5. doi:10.3168/ jds.2009-2234

Hoffman, J. R., \& Flavo, M. (2004). Protein which is best? Journal of Sports Science and Medicine, 3(3), 118-130. Retrieved from http: / / www.jssm.org / vol3 / n3 / 2 / v3n3-2pdf.pdf

Karleskind, D., Laye, I., Halpin, E., \& Morr, C. V. (1991). Improving acid production in soy-based yogurt by adding cheese whey proteins and mineral salts. Journal of Food Science, 56(4), 999-1001. doi:10.1111/j. 1365-2621.1991.tb14626.x

Karlsson, A. O., Ipsen, R., Schrader, K., \& Ardo, Y. (2005). Relationship between physical properties of casein micelles and rheology of skim milk concentrate. Journal of Dairy Science, 88(11), 3784-3797.

Kumar, P., \& Mishra, H. N. (2004). Mango soy fortified set yoghurt: effect of stabilizer ad- 
dition on physicochemical, sensory and textural properties. Food Chemistry, 87(4), 501-507. doi:10.1016/j.foodchem.2003.12. 022

Larmond, E. (1987). Laboratory methods for sensory evaluation of food. Ottawa, Canada.: Canadian government publishing center.

Layman, D. K., \& Rodriguez, N. R. (2009). Egg protein as a source of power, strength, and energy. Nutrition Today, 44(1), 43-48. Cited By (since 1996): 3. doi:10.1097/NT. 0b013e3181959cb2

Lewko, L., \& Gornowicz, E. (2009). Egg albumen quality as affected by bird origin. Journal of Central European Agriculture, 10(4), 455-464. Retrieved from http : / / jcea . agr . hr / articles / 776_EGG_ALBUMEN_QUALITY_AS_ AFFECTED_BY_BIRD_ORIGIN_en.pdf

Lucey, J. A. (2004). Cultured dairy products: an overview of their gelation and texture properties. International Journal of Dairy Technology, 57(2-3), 77-84. doi:10.1111/j.14710307.2004.00142.x

Marth, E. (1978). Standard methods for the examination of dairy products (14th ed.). Washington, DC.: American public health association.

Minitab statistical guide version 14. (2004). Minitab Inc. Minitab Inc. PA, USA.

Mistry, V. V., \& Hassan, H. N. (1992). Manufacture of nonfat yogurt from a high milk protein powder. Journal of Dairy Science, 75 (4), 947-957.

Öztürk, B. A., \& Öner, M. D. (1999). Production and evaluation of yogurt with concentrated grape juice. Journal of Food Science, 64 (3), 530-532. Cited By (since 1996): 26. doi:10. 1111/j.1365-2621.1999.tb15077.x

Parnell-Clunies, E., Kakuda, Y., Mullen, K., \& Arnott, J., D.R. abd deMan. (1986). Physical-properties of yogurt - a comparison of vat versus continuous heatingsystems of milk. Journal of Dairy Science, 69(10), 2593-2603.

Rasic, J., \& Kurmann, J. (1978). Yoghurt scientific grounds, technology, manufacture and preparation. Copenhagen, Denmark: Technical Dairy Publishing House.
Remeuf, F., Mohammed, S., Sodini, I., \& Tissier, J. P. (2003). Preliminary observations on the effects of milk fortification and heating on microstructure and physical properties of stirred yogurt. International Dairy Journal, 13(9), 773-782. doi:10.1016/S09586946(03)00092-X

Savello, P. a. D. R. (1995). Improved yogurt physical-properties using ultrafiltration and very-high temperature heating. Milchwissenschaft-milk Science International, 50(2), 86-90.

Solanki, G., \& Rizvi, S. S. H. (2001). Physicochemical properties of skim milk retentates from microfiltration. Journal of Dairy Science, 84 (11), 2381-2391.

Stadelmann, W. (1992). Eggs and egg products. In Y. Hui (Ed.), Encyclopedia of food science and technology (Vol. 2). New York: Wiley-Interscience.

Supavititpatana, P., Wirjantoro, T. I., \& Raviyan, P. (2009). Effect of sodium caseinate and whey protein isolate fortification on the physical properties and microstructure of corn milk yogurt. Chiang Mai University Journal of Natural Sciences, 8(2), 247-263.

Tamine, A., \& Deeth, H. (1980). Yogurt: technology and biochemistry. Journal of Food Protection, 43, 939.

Uysal, H., Kilic, S., Kavas, G., Akbulut, N., \& Kesenkas, H. (2003). Some properties of set yoghurt made from caprine milk and bovine-caprine milk mixtures fortified by ultrafiltration or the addition of skim milk powder. International Journal of Dairy Technology, 56(3), 177-181. doi:10. 1046/j.1471-0307.2003.00101.x 